\title{
SEJARAH BANDARUDARA SUGIMANURU DI DESA KUSAMBI KECAMATAN KUSAMBI KABUPATEN MUNA BARAT (1980-2017) ${ }^{1}$
}

\author{
Oleh \\ Jaldin $^{2}$, Dade Prat Untarti ${ }^{3}$
}

\begin{abstract}
ABSTRAK: Tujuan utama penelitian ini adalah (1) Untuk mendeskripsikan latar belakang pembangunan bandarudara Sugimanuru di Desa Kusambi Kecamatan Kusambi Kabupaten Muna Barat (2) Untuk menguraikan kendala pembangunan bandar udara Sugimanuru di Desa Kusambi Kecamatan Kusambi Kabupaten Muna Barat (3) Untuk menguraikan dampak pembangunan bandar udara Sugimanuru di Desa Kusambi Kecamatan Kusambi Kabupaten Muna Barat, dan (4) Untuk menguraikan perkembangan pembangunan bandar udara Sugimanuru di Desa Kusambi Kecamatan Kusambi Kabupaten Muna Barat.

Metode yang digunakan dalam penelitian ini adalah metode sejarah yang dikemukakan oleh Helius Sjamsuddin, yang terdiri atas tiga tahap yaitu: (1) Heuristik yakni mencari sumber melalui wawancara, studi kepustakaan, dan penelitian lapangan, (2) Kritik Sumber terdiri atas kritik eksternal dan kritik internal guna untuk mendapat data yang otentik, (3) Historiografi yaitu tahap penulisan dalam bentuk karya tulis kronologis, sistematis, dan ilmiah. Hasil penelitian lapangan menunjukkan bahwa: (1) Latar belakang pembangunan bandar Udara Sugimanuru pada awal pembangunannya atas dasar pemikiran seorang pemimpin yang bernama Drs. La Ode Saafi Amane yang merupakan Bupati Muna periode 1981-1986 yang menjunjung tinggi empat poin visi dan misi yaitu: mendorong peningkatan dan pemerataan kesejahteraan masyarakat, meningkatkan kualitas dan daya dukung infrastruktur wilayah, meningkatkan kualitas pelayanan publik, meningkatkan pengelolaan dan pelestarian sumber daya alam. Atas dasar itulah sehingga terbangun bandar udara Sugimanuru untuk pelayanan sipil, (2) Kendala pembangunan bandar udara Sugimanuru yaitu dapat dilihat dari pandangan masyarakat yang diwujudkan dalam bentuk respon yaitu ada pihak yang menerima pembangunan bandar udara Sugimanuru dan ada pihak yang menolak pembangunan bandar udara Sugimanuru, (3) Dampak dari pembangunan bandar udara Sugimanuru yakni terbukanya lapangan kerja bagi masyarakat, mendorong pertumbuhan ekonomi masyarakat, bertambahnya alat transportasi, mempermudah akses transportasi lintas daerah. (4) Perkembangan pembangunan bandar udara Sugimanuru dari tahun ketahun terlihat mengalami perkembangan yang signifikan, hal itu dapat dilihat dari sarana dan prasarana yang ada.
\end{abstract}

Kata Kunci: Kendala, Perkembangan, Bandar Udara

\section{PENDAHULUAN}

Sistem transportasi udara di Indonesia semakin berperan dalam pembangunan perekonomian dan merupakan kewenangan transportasi udara untuk dapat melayani seluruh wilayah nusantara terutama dalam kaitanya dengan percepatan arus informasi, barang, penumpang dan lain sebagainya. Pembangunan diharapkan dapat meningkatkan perkembangan ekonomi masyarakat diwilayah sekitarnya dan dapat meningkatkan kesejahteraan masyarakat pada umumya. Menurut Widjaya, (1982: 14) bahwa pembangunan merupakan upaya meningkatkan kemampuan manusia untuk mempengaruhi masa depannya. Dalam pembangunan sistem transportasi di Indonesia semakin berperan dalam pengembangan perekonomian serta bertujuan untuk mempercepat arus trasportasi, informasi, sehingga mampuh mempercepat perjalanan penumpang, barang dan lain sebagainya.

\footnotetext{
${ }^{1}$ Disandur dari hasil Penelitian

${ }^{2}$ Alumni Jurusan Pendidikan sejarah

${ }^{3}$ Dosen FKIP UHO
} 
E-ISSN: 2502-6674

P-ISSN: 2502-6666

http://ojs.uho.ac.id/index.php/p_sejarah_uho

Pembangunan bandar udara Sugimanuru merupakan bandar udara yang terletak di Desa Kusambi Kecamatan Kusambi Kabupaten Muna Barat. Rencana pembangunan Bandar Udara Sugimanuru merupakan pembangunan yang cukup besar di Kabupaten Muna dan Muna Barat dan memerlukan dana yang sangat besar. Namun demikian rencana pembangunan bandara Sugimanuru tidak langsung mendapat persetujuan oleh semua pihak masyarakat Muna Barat. Namun dalam proses pelaksanaan pembangunan bandara mendapat penolakan dari pihak masyarakat yang akan terkena dampak langsung pembangunan khususnya masyarakat petani yang merupakan pemilik lahan sebagai lokasi pembangunan bandara yang beranggapan bahwa dengan pembangunan bandara di lokasi tersebut dapat menyebabkan hilangnya sumber mata pencaharian mereka.

Sejarah bandar udara Sugimanuru dapat diketahui dari respon dan pandangan masyarakat berkaitan dengan pembangunan bandara Sugimanuru serta kecenderungan rencana yang akan dilakukan pasca bandara terbangun. Respon masyarakat yang dimaksud yaitu respon masyarakat tentang pembangunan bandara Sugimanuru. Misalnya, ada pihak yang menerima pembangunan bandara Sugimanuru dan ada juga pihak yang menolak pembangunan bandara Sugimanuru.

\section{KAJIAN PUSTAKA}

Sartono Kartodirjo (2002: 89) membagi sejarah menjadi dua yaitu sejarah dalam arti objektif yang merupakan kejadian dan peristiwa sejarah yang tidak dapat terulang dan sejarah dalam arti subjektif atau suatu kontruksi (bangunan) yang disusun oleh penulis sebagai suatu uraian cerita (kisah). Kisah tersebut merupakan suatu kesatuan rangkaian dari fakta-fakta yang berkaitan.

Pada dasarnya suatu ilmu tidak dapat berdiri sendiri melainkan saling berkaitan antara satu sama lain. Ilmu sejarah misalnya untuk mengetahui perkembangan ilmu-ilmu pengetahuan yang lain sangat membutuhkan ilmu sejarah, karena fungsi ilmu sejarah adalah upaya penelusuran jejak-jejak masa lampau sehingga yang ada sekarang menjadi jelas. Menurut M. Dien Madjid (2014: 8) mengemukakan bahwa sejarah adalah cabang ilmu pengetahuan yang mengkaji secara sistematis keseluruhan perkembangan, proses perubahan atau dinamika kehidupan masyarakat dengan segala aspek kehidupannya yang terjadi dimasa lampau.

Menurut Kuntowijoyo (1995: 210), mengemukakan bahwa sejarah adalah ilmu yang mandiri. Mandiri artinya mempunyai filsafat ilmu sendiri, permasalahan sendiri, dan penjelasan sendiri yang dimana sejarah menafsirkan, memahami dan mengerti dimulai dengan menunjukan kekhasan sejarah sebagai ilmu. Setelah mengetahui sejarah sebagai ilmu, maka perihal penjelasan sejarah, sehubungan dengan jenis ilmu. Ada tiga hal yang harus kita pahami yaitu: (1) penjelasan sejarah adalah hermeneutik dan verstehen, menafsirkan dan mengartikan, (2) penjelasan sejarah adalah penjelasan tentang waktu yang memanjang, (3) penjelasan sejarah adalah penjelasan tentang peristiwa tunggal.

Transportasi mencakup bidang yang sangat luas karena hampir seluruh kehidupan manusia tidak terlepas dari kegitan transportasi, transportasi tumbuh dan berkembang sejalan dengan majunya tingkat kehidupan dan budaya manusia. Kehidupan manusia yang maju ditandai oleh mobilitas yang memadai dengan tersedianya mobilitas dan prasarana yang cukup memadai. Widjaya dan Hartono (1986: 15) mengemukakan bahwa transportasi memungkinkan pemindaan sistematis manusia dan barang dari suatu tempat ke tempat yang lain. Jelas merupakan hal yang sangat pokok dalam berbagai interaksi dalam sistem distribusi barang. Sejalan dengan itu berbicara tentang transportasi merupakan sarana yang dapat memindahkan orang atau barang-barang keperluan manusia yang tidak terlepas adanya faktor ekonomi. Transportasi atau pengangkutan merupakan sarana ekonomi yang berfungsi untuk menunjang pemindahan sesuatu (manusia, hewan dan barang) dari suatu tempat asal ketempat satu tujuan dengan maksud untuk menciptakan kegunaan tempat (place utility) dan kegunaan waktu (time utility) (Kamaluddin, 1997: 68).

Pembangunan dapat diartikan sebagai perubahan yang berencana, dimana adanya suatu kenyataan fisik dan keadaan jiwa yang diupayakan oleh masyarakat sebagai subyek dari pembangunan yang dilaksanakan melalui suatu kombinasi sebagai suatu proses sosial, ekonomi, dan kelembagaan untuk menuju pada kehidupan yang lebih baik. Pembangunan bukan saja perubahan dalam bentuk fisik semata tetapi juga menitikberatkan pada jiwa spiritual sehingga dapat 
E-ISSN: 2502-6674

P-ISSN: 2502-6666

http://ojs.uho.ac.id/index.php/p sejarah uho

diharapkan terjadi suatu keselarasan atau keseimbangan. Kunarjo (1992: 65) bahwa pembangunan infrastruktur transportasi bandar udara mampuh mendorong pertumbuhan ekonomi baik itu di dalam wilayahnya maupun di wilayah sekitarnya.

Menurut Tjokroamidjojo (1995: 38) pembangunan merupakan suatu perencanaan yang terorganisir serta didukung pula terhadap kemungkinan penyempurnaan administrasi negara yang dapat dilakukan dengan dua pendekatan: (1) usaha perbaikan dan penyempurnaan secara menyeluruh, (2) perbaikan dan penyempurnaan administrasi yang dilakukan secara sebagiansebagian.

Menurut Kamaluddin (1991: 2) pembangunan daerah merupakan kebijakan nasional pemerintah dalam melaksanakan pembangunan di daerah yang dilakukan secara bertahap bertumpu pada tujuan untuk tercapainya trilogi pembangunan, yaitu: (1) pemerataan pembangunan dan hasilhasilnya yang menuju pada tercapainya keadilan sosial bagi seluruh rakyat, (2) pemerataan kesempatan memperoleh pendidikan dan pelayanan kesehatan, (3) pemerataan pembagian pendapatan, (4) pemerataan kesempatan kerja.

Pembangunan merupakan suatu proses yang bertujuan memajukan keadaan sosial ekonomi masyarakat, yang mana masyarakat dapat ikut serta berusaha secara aktif dalam pelaksanaan pembangunan. Pembangunan merupakan suatu rangkaian usaha pertumbuhan dan perubahan yang berencana yang dilakukan secara sadar oleh suatu bangsa, negara, atau pemerintah menuju modernisasi dalam rangka pembinaan bangsa (Widjaya, 1982: 3).

Menurut Hugiono, (1984: 4) adalah seluruh perkembangan masyarakat pada masa lampau dinilai secara kritis dan akhirnya dijadikan perbendaharaan pedoman bagi penilaian dan penentuan pedoman sejak sekarang serta kearah progres masa depan. Pengertian perkembangan erat kaitanya dengan perkembangan dari segi tujuan yaitu kemajuan atau perluasan dengan melakukan beberapa usaha. Hanya saja yang membedakan adalah masalah waktu, sedangkan pengembangan tidak mengacu pada waktu.

Menurut Poerwadarminta (1987: 472) bahwa berkembang berarti terbuka menjadi luas dan besar atau menjadi bertambah sempurna dan banyak yang maju. Manusia dalam perkembangannya melewati beberapa tahapan, sehingga manusia disebut manusia berbudaya, kehidupan manusia pada umumnya tergantung pada kondisi hasil-hasil alam yang dimilikinya sehingga manusia mampuh bersaing dan menjadi berkembang seiring kemajuan ilmu pengetahuan dan teknologi pada suatu masyarakat tersebut.

\section{METODE PENELITIAN}

Penelitian ini dilaksanakan Desa Kusambi Kecamatan Kusambi yang merupakan lokasi bandar udara Sugimanuru. Jenis penelitian ini merupakan penelitian sejarah yang bersifat deskriptif kualitatif yakni penulis memberikan gambaran secara jelas tentang latar belakang sejarah bandar udara Sugimanuru di Desa Kusambi Kecamatan Kusambi Kabupaten Muna Barat, untuk menjelaskan kendala pembangunan bandar udara Sugimanuru di Desa Kusambi Kecamatan Kusambi Kabupaten Muna Barat, dampak pembangunan bandar udara Sugimanuru di Desa Kusambi Kecamatan Kusambi Kabupaten Muna Barat, dan perkembangan bandar udara Sugimanuru di Desa Kusambi Kecamatan Kusambi Kabupaten Muna Barat. Sedangkan sumber data yang digunakan terdiri atas (1) Sumber tertulis, yaitu data yang diperoleh dalam bentuk buku, skripsi, arsip, dan sumber tertulis lainnya. Sumber-sumber tersebut diperoleh di perpustakaan Universitas Halu Oleo, perpustakaan Daerah Sulawesi Tenggara, Kantor Kecamatan Kusambi, dan Kantor Dinas Perikanan Kabupaten Muna Barat. (2) Sumber lisan, data yang diperoleh dari keterangan lisan melalui hasil wawancara pemerintah setempat dan hasil wawancara dari tokoh masyarakat yang kompeten dibidang penelitian ini. (3) Sumber visual, melalui data-data yang dikumpulkan dari hasil pengamatan mengenai Bandar udara Sugimanuru.

Teknik pengumpulan sumber data yang digunakan peneliti mengacu pada pendapat Sjamsuddin, (2007: 17-239) yaitu dengan melakukan penelitian kepustakaan (Library Research), penelitian lapangan (field research) yaitu kegiatan yang dilakukan dalam mencari data dengan melakukan peninjauan langsung di lapangan. Penelitian lapangan dilakukan dengan dua cara yakni 
E-ISSN: 2502-6674

P-ISSN: 2502-6666

http://ojs.uho.ac.id/index.php/p_sejarah_uho

pengamatan (observasi), yakni peneliti melakukan pengamatan secara langsung terhadap permasalahan yang diteliti, yakni tentang pembangunan bandar udara Sugimanuru di Kecamatan Kusambi Kabupaten Muna Barat, dan wawancara (interview) yakni peneliti mengadakan wawancara atau tanya jawab dengan masyarakat yang dipercaya banyak mengetahui permasalahan yang diteliti sehingga dapat diperoleh data-data dan informasi yang dibutuhkan. Untuk mengetahui keaslian dan kebenaran data yang diperoleh, maka peneliti mengadakan kritik sumber yang ditempuh malaui dua tahap yakni kritik eksternal dan kritik internal sehingga data yang diperoleh benar-benar akurat dan dapat dipertanggung jawabkan secara ilmiah. Sedangkatan tahapan akhir dalam penelitian ini adalah tahapan penulisan sejarah yang terdiri dari nurut Interpretasi (Penafsiran), Eksplanasi (Penjelasan) dan Ekspose (Penyajian)

\section{HASIL PENELITIAN DAN PEMBAHASAN}

\section{Latar Belakang Pembangunan Bandar Udara Sugimanuru di Desa Kusambi Kecamatan Kusambi Kabupaten Muna Barat}

Pada awalnya pembangunan bandar udara Sugimanuru dibangun atas dasar pemikiran seorang pemimpin yang bernama Drs. La Ode Saafi Amane yang merupakan Bupati Muna periode 1981-1986 yang menjunjung tinggi empat poin visi dan misi yaitu (1). Mendorong peningkatan dan pemerataan kesejahteraan masyarakat, (2). Meningkatkan kualitas dan daya dukung infrastruktur wilayah, (3). Meningkatkan kualitas pelayanan publik, (4). Meningkatkan pengelolaan dan pelestarian sumber daya alam. Atas dasar visi dan misi itulah sehingga Drs. La Ode Saafi Amane mengungkapkan alasan dibangunnya bandar udara Sugimanuru dengan maksud ingin mempercepat daya tempuh masyarakat dengan bandar udara sebagai transportasi pendukung, dan ingin menghubungkan Kabupaten Muna dengan daerah-daerah lain di Sulawesi Tenggara.

Bandar udara Sugimanuru Adalah bandar udara yang terletak di Kabupaten Muna Barat, tepatnya di Desa Kusambi, Kecamatan Kusambi, Kabupaten Muna Barat, Provinsi Sulawesi Tenggara. Nama Sugimanuru diambil dari nama raja Muna ke-6 yang terkenal adil dan bijaksana, memiliki wawasan luas serta sangat ahli dalam ilmu ketatanegaraan. Dikalangan masyarakat Muna Sugimanuru dikenal dengan gelar omputo mepasokino adhati yang artinya Raja yang menetapkan hukum, adat, nilai-nilai dan falsafah dasar berbangsa dan bernegara. Gelar Sugimanuru diberikan karena pada masa pemerintahanya dirumuskan dan ditetapkan tatanan, nilai-nilai dalam kehidupan berbangsa dan bernegara di Kerajaan Muna. Raja Sugimanuru menetapkan tatanan kehidupan bermasyarakat dengan menetapkan relevansi wilayah dalam hubunganya manusia, alam, dan Tuhan. Penetapan hubungan wilayah dengan manusia tersebut dipengaruhi oleh ajaran dan nilainilai islam.

Muliati mengatakan bahwa, luas lahan bandar udara Sugimanuru adalah $1.250 .000 \mathrm{~m}^{2}$ dalam pembangunan Bandar udara Sugimanuru lokasi yang digunakan adalah tanh milik masyarakat yang dibayar dengan sistem ganti rugi saat itu senilai 100-200 rupiah/meter (Muliati, wawancara 24 September 2018). Bandar udara Sugimanuru Muna berubah menjadi bandara penghubung antar daerah di Sulawesi Tenggara sejak tahun 1984-1985 yang ditandai dengan beroperasinya pesawat jenis Casa yang melayani rute Makasar-Bau-bau-Muna. Namun pengoperasian bandar udara Sugimanuru pada tahun 1984 tersebut tidak berlangsung lama karena disebabkan beberapa faktor diantaranya, pada tahun 1984 lahan bandar udara Sugimanuru belum memiliki surat sertifikat yang sah, banyaknya masyarakat yang menolak adanya bandar udara Sugimanuru, tidak memiliki batas lahan yang jelas dan tidak memiliki pagar keliling menyebabkan hewan ternak bebas masuk diarea bandar udara dan dapat mengancam keselamatan maskapai yang beroperasi, dan lain-lain. Bandar udara Sugimanuru Kembali beroperasi pada tahun 2010, dan setelah terbentuk Kabupaten Muna Barat pada tahun 2014 pemerintah daerah dalam hal ini L.M Rajiun Tumada Kembali memprioritaskan pembangunan infrastruktur salah satunya bandara dan pada tahun 2017 bandara kembali beroperasi dan pemerintah daerah memberikan subsidi sebesar 8 miliar/tahun sebagai jaminan maskapai yang beroperasi. 
E-ISSN: 2502-6674

P-ISSN: 2502-6666

http://ojs.uho.ac.id/index.php/p sejarah uho

Sesuai dengan perkembangan jaman bandar udara Sugimanuru sudah termasuk dalam tatanan kebandarudaraan nasional sebagai bandar udara exiting. Selanjutnya bandar udara Sugimanuru berdasarkan penggunaannya termasuk bandar udara domestik yang melayani rute penerbangan dalam Negeri dengan hirarki sebagai bandar udara pengumpan dan klasifikasi landas pacu 3C. Hirarki adalah bandar udara yang mempunyai cakupan pelayanan yang luas dasri berbagai bandar udara yang melayani penumpang dan kargo dalam jumlah besar sehingga dapat mempengaruhi perkembangan ekonomi secara nasional atau berbagai provinsi.

Bandar udara pengumpan merupakan (a). Bandar udara yang mempunyai cakupan pelayanan dan mempengaruhi perkembangan ekonomi lokal, (b). Bandar udara tujuan atau bandar udara penunjang dari bandar udara pengumpul, (c). Bandar udara sebagai salah satu prasarana penunjang pelayanan kegiatan lokal. Landasan pacu adalah suatu daerah persegi panjang yang ditentukan pada bandar udara di daratan atau perairan yang dipergunakan untuk pendaratan dan lepas landas pesawat udar.

\section{Kendala Pembangunan Bandara Sugimanuru di Desa Kusambi Kecamatan Kusambi Kabupaten Muna Barat}

Rencana pembangunan bandar udara yang ada di Desa Kusambi Kecamatan Kusambi Kabupaten Muna Barat Sulawesi Tenggara merupakan pembangunan yang memerlukan waktu yang cukup panjang dan dana yang sangat besar. Namun adanya pembangunan bandar udara ternyata tidak langsung disetujui oleh semua pihak masyarakat yang ada di Desa Kusambi. Dalam proses pelaksanaan Pembangunan bandar udara Sugimanuru ada penolakan dari pihak masyarakat yang akan terkena dampak langsung pembangunan Bandar udara Sugimanuru. Masyarakat yang terkena dampak langsung pembangunan Bandar udara yang sebagian besar mata pencahariannya sebagai petani yang beranggapan bahwa apabila pembangunan Bandar udara Sugimanuru terlaksana maka mata pencaharian mereka akan hilang.

Kendala dan perkembangan bandar udara Sugimanuru dapat dilihat dari pandangan masyarakat yang diwujudkan dalam bentuk respon dari masyarakat berkaitan dengan pembangunan bandar udara Sugimanuru serta kecenderungan rencana akan di lakukan pasca bandara terbangun. Respon yang dimaksud adalah respon mengenai pembangunan Bandar udara Sugimanuru misalnya, dari satu pihak menerima adanya bandar udara Sugimanuru dipihak lain ada yang menolak pembangunan Bandar udara Sugimanuru. (La firusu, wawancara 24 september 2018).

Setelah tersebarnya kabar akan dibangunnya Bandar udara Sugimanuru yang dimana menggunakan tenaga masyarakat dengan upah yang rendah, maka ratusan lapisan masyarakat turun kejalan, melakukan demonstrasi menolak dan mengancam pemerintah setempat untuk tidak melanjutkan pembangunan bandar udara Sugimanuru. Hal yang sama diungkapkan oleh La Firusu bahwa banyak masyarakat melakukan demonstrasi disekitar lokasi pembangunan bandara membawa benda tajam serta melakukan penutupan area jalan menuju lokasi pembangunan Bandar udara Sugimanuru (La Firusu, wawancara 24 september 2018).

Hampir $80 \%$ masyarakat dan anggota parlemen Muna menolak gagasan pembangunan Bandar udara Sugimanuru yang disebabkan oleh ketidak mampuan mereka untuk bekerja dan ketidak sepahaman mereka dengan alur pemikiran pemerintah daerah pada waktu itu. Seperti yang diungkapkan oleh Wa Sailu yang kala itu menjadi saksi pembangunan bandar udara Sugimanuru bahwa banyak masyarakat yang menolak dibangunnya bandar udara Sugimanuru di atas tanah yang mereka klaim sebagai tanah warisan leluhur, yang pada kenyataanya tanah tersebut adalah tanah milik masyarakat yang ada disekitar area pembangunan bandara (Wa Sailu, wawancara 25 September 2018).

Masyarakat pun melakukan ancaman kepada pemerintah daerah bahwa siapa yang berani membangun bandara di atas tanah warisan nenek moyang mereka maka sampai mati mereka akan menolaknya (Wa Sailu, wawancara 25 September 2018). La Bia mengatakan bahwa, banyak masyarakat yang datang kelokasi pembangunan bandar udara Sugimanuru untuk memblokade jalan menuju area pembangunan bandar udara, mereka menanam pohon pisang ditengah jalan dan mereka menanam pohon kelapa di lokasi pembangunan Bandar udara sebagai tanda tanah tersebut 
E-ISSN: 2502-6674

P-ISSN: 2502-6666

http://ojs.uho.ac.id/index.php/p_sejarah_uho

tidak diizinkan untuk dilakukannya pembangunan. Demonstrasi tersebut terjadi berhari-hari, bahkan berbulan-bulan siang dan malam yang mana ancaman mereka tidak main-main sehingga menyebabkan mandor pembangunan bandar udara Sugimanuru ingin mundur dari pekerjaannya. Mendengar hal tersebut pemerintah daerah secepatnnya mengambil tindakan dengan meminta bantuan kepolisian untuk mengamankan area bandara yang sedang dalam proses penggarapan landasan pacu, tetapi meski polisi sudah turun tangan mengamankan, tetap saja tidak bisa membendung ratusan masyarakat yang melakukan demonstrasi di area bandara (La Bia, wawanara 25 September 2018).

Semua anggota DPRD Muna menolak gagasan pembangunan Bandar udara Sugimanuru tersebut. Mereka beranggapan bahwa membangun bandara didaerah khususnnya daerah terpencil hanya membuang-buang anggaran karena tidak ada perusahaan asing yang ingin berinvestor didaerah tersebut karena tidak ada sumber daya alam yang menarik minat investor untuk menanamkan modalnnya. Kabupaten Muna barat merupakan kabupaten baru yang tidak menyimpan kekayaan alam yang bisa manarik perinvestor dan pemerintah untuk membangun infrastruktur di daerah tersebut. Karena beberapa alasan diatas masyarakat dan anggota DPRD Muna menolak rencana pembangunan bandara. Disamping itu, hal yang sama diungkapkan oleh La Kaimani bahwa dalam pembangunan bandar udara Sugimanuru masyarakat dan jajaran anggota DPRD Muna menolak rencana pembanguan bandar udara Sugimanuru. Hampir setiap hari bahkan sampai berbulan-bulan siang dan malam Kantor Bupati dan rumah jabatannya didatangi ratusan masyarakat laki-laki dan perempuan, dewasa dan anak-anak, mereka berdemonstrasi berteriak menolak rencana pembangunan bandara (La Kaimani, wawancara 25 September 2018).

Setelah menghadapi sekian lama demonstrasi dari masyarakat, dan akhirnya pada tahun 1984-1985 bandara udara Sugimanuru resmi beroperasi melayani rute Makasar-Bau-bau-Muna. Namun pengopersaian bandara ini tidak berlangsung lama karena mendapat tentangan dari masyarkat tentang sertifikat kepemilikan lahan belom ada. Sekian lama berhenti beroperasi bandar udara Sugimanuru dan pada tahun 1992 Pemerintah Daerah Muna mengusulkan kepada pemerintah pusat tentang izin kepemilikan sertifikat tanah yang sah, dan pada akhirnya pada tahun 1993 lokasi bandar udara Sugimanru sudah memiliki izin kepemilikan tanah yang sah dari pemerintah pusat, namun tidak memiliki izin untuk dioperasikan kembali bandar udara Sugimanuru. Setelah melewati waktu yang panjang tanpa ada kegiatan apa-apa dalam bandara sehingga pada tahun 2010 bandar udara Sugimanru kembali beroperasi dengan jenis pesawat yang sama dan melayani rute yang sama dengan sebelumnya namun tidak berlangsung lama. Pada tahun 2014 setelah terbentuknya daerah Kabupaten Muna Barat sebagai daerah otonomi baru maka pemerintah daerah dalam hal ini bupati Muna Barat L.M Rajiun Tumada mengusulkan untuk pengoperasian kembali Bandar udara Sugimanuru, pemerintah daerah memberikan subsidi sebesar 8 miliar/tahun sebagai jaminan maskapai yang beroperasi di bandar udara Sugimanuru, dan akhirnya mendapat respon positif dari pemerintah pusat maka pada tahun 2017 bandar udara Sugimanuru resmi beroperasi.

\section{Dampak Pembangunan Bandar Udara Sugimanuru di Desa Kusambi Kecamatan Kusambi Kabupaten Muna Barat}

Dengan kian berkembangnya dunia penerbangan, keberadaan bandar udara (bandara) sebagai terminal terbang dan mendaratnya pesawat menjadi strategis. Tidak heran jika diberbagai negara, termasuk Indonesia pembangunan bandara terus digiatkan. Bahkan, dikabupaten Muna Barat meski dalam pembangunan bandar udara Sugimanuru tersebut penuh tantangan yang berlikuliku hingga akhirnya berhasil terbangun sebuah bandar udara Sugimanuru bisa menunjang perekonomian masyarakat di Kabupaten Muna Barat. Namun, selain manfaatnya yang banyak, keberadaan bandara juga kian dirasakan menjadi besar bahkan mengganggu sebagian masyarakat, terutama yang tinggal disekitar lokasi bandara.

Dampak terhadap pembangunan bandar udara Sugimanuru di Desa Kusambi Kecamatan Kusambi Kabupaten Muna Barat dapat dilihat dari dampak positif dan dampak negatif sebagai berikut:

1. Dampak Positif 
E-ISSN: 2502-6674

P-ISSN: 2502-6666

http://ojs.uho.ac.id/index.php/p sejarah uho

Dampak positif terhadap pembangunan bandar udara Sugimanuru di Desa Kusambi Kecamatan Kusambi Kabupaten Muna Barat diantaranya sebagai berikut: (a) Terbukanya lapangan kerja bagi masyarakat yang tidak atau yang sedang mengangur diwilayah sekitar lokasi bandar udara Sugimanuru terkhusus adalah masyarakat yang ada di Desa Kusambi. (b) Pertumbuhan ekonomi masyarakat yang ada di Muna Barat khususnya di Desa Kusambi Kecamatan Kusambi membaik. (c) Bertambahnnya alat transportasi di Kabupaten Muna Barat. (d) Mempermudah akses transportasi lintas daerah.

2. Dampak negatif.

Dampak negatif terhadap pembanguanan bandar udara Sugimaru di Desa Kusambi Kecamatan Kusambi Kabupaten Muna Barat diantarannya adalah sebagai berikut: (a) Aspek keselamatan bagi warga yang tinggal disekitar bandara Sugimanuru kurang aman. (b) Lahan pertanian warga sekitar bandara Sugimanuru berkurang. (c) Menimbulkan polusi dan kebisingan bagi msyarakat yang tinggal disekitar bandara Sugimanuru. (d ) Terjadi transisi budaya masyarakat akibat bertambahnya pengunjung yang membawa budaya berbeda dengan budaya masyarakat lokal. (e) Mengurangi pendapatan pengusaha transportasi laut.

\section{Perkembangan Bandar Udara Sugimanuru dari tahun 1980-2017}

Perkembangan bandar udara Sugimanuru dari tahun ketahun semakin digiatkan dan diperbaiki supaya menjadi bagus, dimana bandar udara yang menjadi kebanggaan masyarakat tersebut dimanfaatkan semaksimal mungkin dan didukung oleh pembangunan tambahan infrastruktur bandara terus berkelanjutan hingga saat ini. Disamping itu, masyarakat memanfaatkan bandar udara Sugimanuru sebagai alternatif yang memungkinkan perjalanan masyarakat bisa dijangkau dengan cepat. Bandara udara Sugimanuru yang ada di Desa Kusambi Kabupaten Muna Barat terus menunjukan kemanjuanya, baik dari segi penerbangannya maupun infrastruktur yang terus diperbaharui. Dalam perkembangannya pemerintah daerah terus mengupayakan pembangunan bandar udara Sugimanuru yang mana pembangunan landasan pacu 1400 meter teraspal dan siap didarati pesawat sejenis ATR 72-600 dengan kapasitas 70 tempat duduk. Pemerintah daerah Muna Barat juga terus melakukan lobi ke DPR RI untuk pembangunan landasan pacu lanjutan 1700 meter dengan biaya APBN. Dan Lobi Pemerintah daerah Muna Barat tersebut berhasil (Sitti Nuhra, wawancara 12 September 2018).

Tercatat ditahun 2014, pembangunan tahap lanjutan bandar udara Sugimanuru dilanjutkan dengan penambahan landasan pacu 200 x 30 meter dengan anggaran APBN tahun 2014. Dalam proses pelaksanaan pembangunan lanjutan ini tidak ada masyarakat yang melakukan protes dan demonstrasi karena merupakan bagian keberhasilan pemerintah daerah dalam hal ini Bupati Muna Barat meyakinkan masyarakat bahwa pembangunan bandar udara Sugimanuru bukan semata-mata untuk kepentingan pemerintah melainkan untuk memperbaiki ekonomi masyarakat, tandasnya. Masyarakat juga akhirnya merasakan manfaat dari kehadiran bandar udara Sugimanuru yang telah mengubah gerak aktifitas masyarakat Muna Barat dan juga mengubah gerak hidup setiap penduduknya. Sejak tahun 2017, Muna Barat telah memiliki bandara udara dengan panjang landasan pacu 1.700 meter dengan rincian runway 1.500 meter, serta dilengkapi terminal penumpang. Bandara yang kelahiranya memiliki cerita yang panjang ini resmi terdaftar di Kementrian Perhubungan sebagai salah satu bandara di Indonesia. Karena jumlah penumpang terus bertambah, maskapainya pun berganti Lion Air (Wings Air) yang terbang empat kali dalam seminggu: senin, rabu, Kamis, jumat.

Sebelum dioperasikan kembali bandar udara Sugimanuru, penerbangan yang beroperasi di Sulawesi Tenggara hanya bandar udara Halu Oleo Kendari (sebelumnya bernama Wolter Monginsidi). Namun saat ini setelah beropesanya bandar udara Sugimanuru di Kabupaten Muna Barat, bandar udara yang beroperasi di Sulawesi Tenggara yaitu: bandar udara Matahora di Wakatobi, bandar udara Betoambari di Bau-Bau, dan bandar udara Sangia Ni Bandera di Kolaka, dengan mengoperasikan pesawat jenis dornier yang sama. Hal tersebut bermakna bahwa, bandar udara Sugimanuru yang ada di Kabupaten Muna Barat yang dioperasikan kemabli tahun 2015 ini 


\section{E-ISSN: 2502-6674}

P-ISSN: 2502-6666

http://ojs.uho.ac.id/index.php/p_sejarah_uho

merupakan bandar udara yang ikut serta dalam penerbangan dalam negeri yang bertujuan untuk mempermudah akses perjalanan masyarakat dalam menempuh perjalanan.

Sejak dioperasikan kembali bandar udara Sugimanuru di Kabupaten Muna Barat ini, perkembangan perekonomian daerah Kabupaten Muna Barat meningkat terutama ekonomi masyarakat di Desa Kusambi sebagai lokasi pembangunan bandar udara Sugimanuru. Sebelum dioperasikan kembali bandar udara Sugimanuru, Desa Kusambi ini merupakan desa tertinggal di Kecamatan Kusambi dengan memfokuskan mata pencaharianya dibidang pertanian saja dan hasilnya tidak dapat meningkatkan perekonomian masyarakat. Dengan adanya bandar udara Sugimanuru, perekonomian di Desa Kusambi berkembang, salah satu fakta yang dapat dilihat dari berkembangnya perekonomian masyarakat yaitu rata-rata masyarakat desa Kusambi sudah $85 \%$ memiliki kendaraan sendiri, baik kendaraan roda dua maupun kendaraan roda empat (La Kaimani, wawancara 22 September 2018).

Perkembangan ekonomi masyarakat Desa Kusambi juga dapat dilihat dari jenis usaha masyarakat yang berkembang disekitar lokasi pembangunan bandar udara Sugimanuru, misalnya La firusu (56 tahun) adalah merupakan warga Desa Kusambi yang membuka usaha sembako dan makanan kue-kue . "sejak tahun 2015 ketika bandar udara Sugimanuru sudah mulai dioperasikan, saya memutuskan untuk membuka usaha sembako, disini saya membuka usaha menjual sembako dan kue-kue. Hasilnya pun cukup lumayan sehari bisa mendapatkan 150-200 ribu rupiah, dan alhamdulillah itu sangat membantu perekonomian keluarga kami sehari-hari (La Firusu, wawancara 23 September 2018).

La Firusu adalah contoh salah seorang masyarakat yang merasakan manfaat dioperasikan kembali bandar udara Sugimanuru di Desa Kusambi. Ada banyak kisah masyarakat yang ada di Desa Kusambi yang kehidupannya mulai membaik dalam beberapa tahun terakhir hingga saat ini. Kebanyakan masyarakat dulunya hanya memusatkan mata pencaharian dibidang pertanian kini mereka bisa membuka usaha lain seberti berjualan untuk mencukupi kebutuhan keluarga mereka. Dengan dioperasikan kembali bandar udara Sugimanuru di Kabupaten Muna Barat banyak masyarakat yang membuka pikiran mereka memanfaatkan adanya bandara tersebut sebagai wujud syukur adanya lapangan kerja baru ditanah kelahiran mereka. Disamping itu, hal lain dapat dilihat dari peningkatan trafik penumpang di bandar udara Sugimanuru dimana pada tahun 2015, tercatat sebanyak 9.200 penumpang tiba, dan 8.250 penumpang berangkat per tahun. Adapun ditahun 2017, trafik penumpang meningkat menjadi 10.235 penumpang tiba dan 11.137 penumpang berangkat per tahunya. Hingga saat ini terus bertambah penumpang baik yang pergi maupun yang tiba di bandar udara Sugimanuru. Berikut dapat dilihat perkembangan bandara Sugimanuru di Kecamatan Kusambi Kabupaten Muna Barat dari tahun berdirinya sampai sekarang ini, dapat dilihat dari tabel beikut:

Tabel. Perkembangan Pembangunan Bandar Udara Sugimanuru tahun 1980-2017 diantaranya adalah sebagai berikut:

\begin{tabular}{|c|c|c|}
\hline Tahun & $\begin{array}{c}\text { Kegiatan } \\
\text { Pembangunan }\end{array}$ & Keterangan \\
\hline 1980-1984 & & $\begin{array}{l}\text { Penentuan lokasi sebagai pembangunan } \\
\text { Sugimanuru }\end{array}$ \\
\hline & $\begin{array}{l}\text { Pembangunan Tahap } \\
\text { awal }\end{array}$ & $\begin{array}{l}\text { Pembangunan landasan pacu sepanjang } 700 \times 30 \text { meter dan } \\
\text { pembangunan terminal } 7 \times 9 \mathrm{~m} \\
\text { dengan anggaran APBN } 1980\end{array}$ \\
\hline 1984-1985 & $\begin{array}{l}\text { Pembukaan rute } \\
\text { Makasar-Bau-bau- } \\
\text { Muna }\end{array}$ & $\begin{array}{l}\text { Pendaratan Helikopter Polda Sultra Menggunakan pesawat jenis } \\
\text { kasa Air jenis PK-VVJ yang berkapasitas } 12 \text { orang Jenis Expres } \\
\text { Air tipe PK-TXO jumlah kapasitas penumpang } 25 \text { orang Jenis } \\
\text { Wings Air tipe ATR } 70 \text { dengan jumlah penumpang } 34 \text { orang }\end{array}$ \\
\hline & $\begin{array}{l}\text { Pembangunan } \\
\text { Lanjutan }\end{array}$ & $\begin{array}{l}\text { Pembangunan landasan pacu } 1.400 \mathrm{~m} \times 30 \mathrm{~m} \text {, Pembangunan } \\
\text { terminal penumpang dengan ukuran } 8 \mathrm{~m} \times 10 \mathrm{~m} \text { dengan dana } \\
\text { APBN 2014, Pembukaan rute Makasar-Muna Barat }\end{array}$ \\
\hline
\end{tabular}


E-ISSN: 2502-6674

P-ISSN: 2502-6666

http://ojs.uho.ac.id/index.php/p sejarah uho

\begin{tabular}{|l|l|l|}
\hline 2016-2017 & $\begin{array}{l}\text { Penambahan Maskapai dengan } \\
\text { Lion Air, Wings Air, dan Garuda }\end{array}$ & $\begin{array}{l}\text { Penambahan jadwal terbang hingga 4 x seminggu diakibatkan } \\
\text { bertambahnya jumlah penumpang setiap hari. Jenis Wing ATR } \\
\text { 72- dengan kapasitas penumpang 69 orang Garuda Indonesia } \\
\text { jenis ATR 72- dengan kapasitas 70 orang penumpang. }\end{array}$ \\
& & \\
\hline
\end{tabular}

Sumber: Kantor Bandar Udara Sugimanuru Kabupaten Muna Barat.

Berdasarkan data di atas, perkembangan Bandara Sugimanuru di Desa Kusambi Kecamatan Kusambi Kabupaten Muna Barat tiap tahunya terus meningkat dari tahun ketahun. Pengoperasian kembali Bandara Sugimanuru ini mimicu pertumbuhan ekonomi, mempermudah akses transpotasi antar daerah masyarakat Kabupaten Muna Barat, mempermudah hubungan sosial politik antara pemerintah pusat dengan pemerintah daerah, memungkinkan hubungan sosial dengan daerah lain terjalin cepat.

\section{KESIMPULAN}

Pada awalnya pembangunan bandar udara Sugimanuru dibangun atas dasar pemikiran seorang pemimpin yang bernama Drs. La Ode Saafi Amane yang merupakan Bupati Muna periode 19811986 yang menjunjung tinggi empat poin visi dan misi yaitu (1). Mendorong peningkatan dan pemerataan kesejahteraan masyarakat, (2). Meningkatkan kualitas dan daya dukung infrastruktur wilayah, (3). Meningkatkan kualitas pelayanan publik, (4). Meningkatkan pengelolaan dan pelestarian sumber daya alam. Atas dasar visi dan misi itulah sehingga Drs. La Ode Saafi Amane mengungkapkan alasan dibangunnya bandara Sugimanuru dengan maksud ingin mempercepat daya tempuh masyarakat dengan bandara sebagai transportasi pendukung, dan ingin menghubungkan Kabupaten Muna dengan daerah-daerah lain di Sulawesi Tenggara.

Bandar udara Sugimanuru Adalah bandar udara yang terletak di Kabupaten Muna Barat, tepatnya di Desa Kusambi, Kecamatan Kusambi, Kabupaten Muna Barat, Provinsi Sulawesi Tenggara. Nama Sugimanuru diambil dari nama raja Muna ke-6 yang terkenal adil dan bijaksana, memiliki wawasan luas serta sangat ahli dalam ilmu ketatanegaraan. Dikalangan masyarakat Muna Sugimanuru dikenal dengan gelar omputo mepasokino adhati yang artinya Raja yang menetapkan hukum, adat, nilai-nilai dan falsafah dasar berbangsa dan bernegara. Gelar Sugimanuru diberikan karena pada masa pemerintahannya dirumuskan dan ditetapkan tatanan, nilai-nilai dalam kehidupan berbangsa dan bernegara di Kerajaan Muna. Raja Sugimanuru menetapkan tatanan kehidupan bermasyarakat dengan menetapkan relevansi wilayah dalam hubunganya manusia, alam, dan Tuhan. Penetapan hubungan wilayah dengan manusia tersebut dipengaruhi oleh ajaran dan nilai-nilai islam. Luas lahan bandar udara Sugimanuru adalah $1.250 .000 \mathrm{~m}^{2}$ dalam pembangunan bandar udara Sugimanuru lokasi yang digunakan adalah tanah milik masyarakat yang dibayar dengan sistem ganti rugi saat itu senilai 100-200 rupiah/meter.

Dampak dibangunya bandar udara Sugimanuru di Desa Kusambi Kecamatan Kusambi Kabupaten Muna Barat yakni terbukanya lapangan kerja baru bagi masyarakat yang tidak atau sedang menganggur di wilayah sekitaran bandar udara Sugimanuru terkhusus adalah masyarakat yang ada di Desa Kusambi, disamping itu meingkatnya ekonomi masyarakat di Desa Kusambi Kecamatan Kusambi Kabupaten Muna Bara. Sedangkan dampak negatif pembangunan bandar udara Sugimanuru diantaranya adalah lahan pertanian masyarakat sekitar bandar udara Sugimanuru berkurang, aspek keselamatan bagi warga yang tinggal disekitar bandar udara Sugimanuru terganggu, bisa menimbulkan polusi dan kebisingan bagi masyarakat yang tinggal disekitar daerah bandar udara Sugimanuru, serta mengurangi pendapatan pengusaha transportasi laut.

Perkembangan pembangunan bandar udara Sugimanuru dari tahun ke tahun semakin meningkat, bandara ini menjadi kebanggaan masyarakat muna yang digunakan dengan semaksimal mungkin. Pembangunan infratruktur tambahan bandara terus berkelanjutan hingga saat ini. Disamping itu, banyak masyarakat lokal dan masyarakat luar menggunakan bandar udara Sugimanuru sebagai alternatif yang memungkinkan perjalanan masyarakat bisa dijangkau dengan cepat. 
E-ISSN: 2502-6674

P-ISSN: 2502-6666

http://ojs.uho.ac.id/index.php/p sejarah uho

\section{DAFTAR PUSTAKA}

Helius Sjamsuddin . 2007. Metodologi Sejarah Jogjakarta: Ombak.

Hugiono dan P K Poerwantana. 1987. Pengantar Ilmu Sejarah. Jakarta: Bina Aksara.

Kamaluddin. 1991. Beberapa Aspek Pelaksanaan Kebijakan Pembangunan Daerah. Jakarta: Lembaga Penerbit Fakultas Ekonomi Universitas Indonesia.

Kuntowijoyo. 1995. Pengantar Ilmu Sejarah. Yogyakarta: Yayasan Benteng Budaya. M. Dien Madjid. 2014. Ilmu Sejarah Sebuah Pengantar. Jakarta: Prenada Media Grup. Poerwadarminta W.J.S, 1982. Kamus Umum Bahasa Indonesia. Jakarta: Balai Pustaka Poerwadarminta, W.J.S. 1987. Kamus Umum Bahasa Indonesia Cetakan VII. Jakarta: Balai Pustaka.

Sartono Kartodirjo. 2002. Teori Sejarah dan Masalah Historiografi. Jakarta: Ghalia Indonesia. Tjokroamidjojo. 1995. Pengantar Administrasi Pembangunan. Jakarta: Pustaka LP3ES.

Widjaya. 1982. Budaya Politik dan Pembangunan Ekonomi. Jakarta: Gramedia. 